\title{
About the Specificity of the Analysis of Socio-Economic Systems in the Conditions of Digitalization
}

\author{
Bryantsev I.I. ${ }^{1 *}$ Bryantseva O.V. ${ }^{2}$ Evstifeev R.V. ${ }^{3}$ \\ ${ }^{1}$ Russian Presidential Academy of National Economy and Public Administration (RANEPA) - Stolypin Volga Region \\ Institute of Administration, Saratov, Russia \\ ${ }^{2}$ Saratov State Law Academy, Saratov, Russia \\ ${ }^{3}$ Vladimir branch of the Russian Presidential Academy of National Economy and Public Administration (RANEPA), \\ Vladimir, Russia \\ *Corresponding author. Email: iibry@yandex.ru
}

\begin{abstract}
The work considers the features of the system paradigm in relation to the analysis of socio-economic and socio-political phenomena. These phenomena are considered from the point of their systemic properties, and their structure is presented as a set of interacting, transforming and evolving subsystems. It is noted that these systems are a part of the world around us, that is stable in time and space, possessing the properties of external integrity and internal diversity. In the conditions of digitalization, new opportunities for disclosing this diversity arise, for example, based on the use of Big Data and the implementation of the technological capabilities of their use in the presence of the necessary mathematical tools, implemented through the creation of appropriate models.

The authors note, that the disclosure of the fractal nature of socio-economic systems allows to form models of their development, taking into account the emerging uncertainties, associated with their interaction with the environment.

The author presents a mathematical model, that allows to take into account all the variety of external effects through the interrelation of the reaction of the object, design, process and environmental subsystems to it. Moreover, their interrelation acts as elements of an order, that preserves the memory of previous states of the system and ensures its reproduction during evolutionary development as a self-similar quasi-resistant to external effects system.
\end{abstract}

Keywords: system paradigm, digitalization, object, project, environment, process, fractal

\section{INTRODUCTION}

The use of digital technologies forms new strategic priorities for social development, transforms society, public relations and their legal regulation.

Comprehension and analysis of this process is carried out by researchers, representing various spheres of scientific knowledge, using the study tools, available to them [1]. As the most capacious study paradigm, the methodology of system analysis can be considered and applied [2].

\section{METHODS OF RESEARCH}

A systematic approach to the analysis of any phenomenon, process, structure in any sphere is quite relevant, as it allows to identify and

study various, sometimes implicit, interrelations [3].
There are various approaches to systematicity. An endogenous approach, where a system is understood as many elements, connected in some way, is developed in the works of classics [4,5]. In an exogenous approach, a system is understood as a certain image of a real phenomenon or a holistic part of the surrounding world, distinguished by some signs, functional or spatial $[6,7]$.

The modern systemic paradigm allows to consider not only the economy, but also social, public phenomena and structures as a combination of interacting, transforming and evolving systems. The socio-economic system is a part of the world around us, that is stable in time and space, possessing the properties of external integrity and internal diversity.

The management of complex socio-economic systems in modern conditions is associated with the use of Big Data, the effectiveness and possibility of using which is associated with the implementation of platform digital technologies, which are based on one or another model of socio-economic processes. Promising study potential in this direction, in our opinion, are in works of G. Kleiner, 
which presents the main methodological approaches to the analysis of economic systems and the consideration of the polymorphism of systems through decomposition into four types of systems: object, design, process and environmental [8]. As the classification criterion, it is the nature of their localization in the space-time framework, where space and time are the main resources for the functioning of the system.

These concepts are analyzed from the point of view of their localization in space and time, and it is shown, that object systems are limited in space and not limited in time, process systems are not limited in space and limited in time, design systems are limited in space and time, environmental systems - not limited in space and time [9]. In addition to the space-time resources of the system, in their operation they use energy, that manifests itself in two forms: the energy, spent on the efficient use of the space, occupied by the system (the characteristic is intensity) and the energy, spent on the effective use of time (the characteristic is activity). That is, intensity and activity are characteristics of energy use.

\section{RESEARCH RESULTS AND DISCUSSION}

Examples of object systems in various spheres and levels include: states, cities, enterprises, courts, authorities, civil society institutions, communication platforms for power and society in the form of public councils and public chambers, as well as individual individuals. Examples of design systems include the creation of information systems, the construction, restructuring of an enterprise, the establishment of a company, their transformation. Examples of process systems are digitalization, higher education system, science, art, innovation. Examples of environmental systems are - codes of the Russian Federation, the Internet, the legal system of the country.

Thus, starting from this methodology, any phenomenon, as a system, can be considered as an interaction, a combination of these four subsystems. Moreover, each phenomenon as a system has a main direction, a main function (object, design, process, environmental).

Consideration in the framework of the system paradigm of digitalization as a system can be represented in the form of such a tetrad, combining design, process, environmental and object subsystems within the framework of a single holistic system of social relations of the functioning and interaction of digitalization objects; digitalization projects and processes, the environment, in which digitalization takes place (see. fig. 1).

Any socio-economic system is a multidimensional phenomenon, that has its own projections in various planes of social life: in the economic, social, political and others. Thus, a systematic analysis of the digitalization process will contribute to economic growth, lower costs, but the process of digitalization itself requires economic costs. In the political sphere, digitalization and the development of information technologies provide a number of advantages, for example, creating technological capabilities for modeling processes in this sphere.

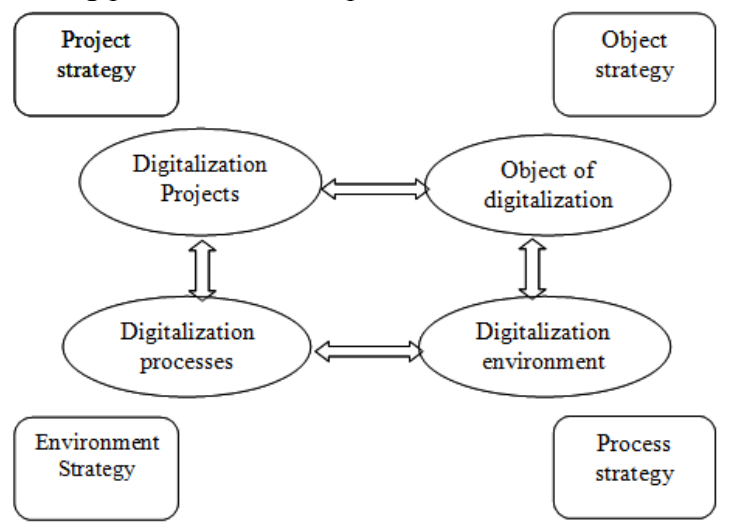

Figure 1 Socio-economic tetrad

In the social sphere, digitalization reduces social inequality and makes many services open and accessible.

In its most general form, the digitalization of socioeconomic systems necessitates the consideration of a wide range of interacting subsystems of subjects from various fields - politics, social, legal, social life, economics, technology, culture, psychology, ideology, etc. At the same time, the result of their socio-economic activity and constant reproduction within the framework of the economic process is ensured through the implementation of a continuous reproductive cycle, consisting of production, distribution, exchange and consumption. The specificity of this chain is that all these stages are implemented simultaneously and are integral components of each other and the entire reproductive cycle. Another inherent specific aspect of interacting subsystems is the unavoidability of solving the polymorphism problem of these subsystems, which manifests itself within each of them in the combination of features of object, design, process, and environmental systems.

In connection with the actualization of the polymorphism problem, note certain circumstance, associated with the reproductive socio-economic cycle, consisting of the processes of production, distribution, exchange and consumption system. Since these processes are in constant interconnection, they can be scaled, and because of this, there is a need to distinguish another process, that reveals their fractal essence (see fig. 2). Let us pay special attention to the fact, that understanding of the fractal nature allows to form models of the development of systems taking into account the emerging uncertainties, associated with their interaction with the environment.

As a result, as the basic set of processes, analyzed in the system, denote:

- $\quad$ PRODUCTION processes, such as maintaining the basic conditions for the functioning of the system, improving the characteristics of the state of the system.

- EXCHANGE processes with the environment or other subsystems; 
- $\quad$ DISTRIBUTION processes, system change using self-organization mechanisms;

- CONSUMPTION processes, change of the internal space of the system, the development of subsystems, coordination with external conditions;

- $\quad$ FRACTAL processes, like scaling based on the generation of similar systems.

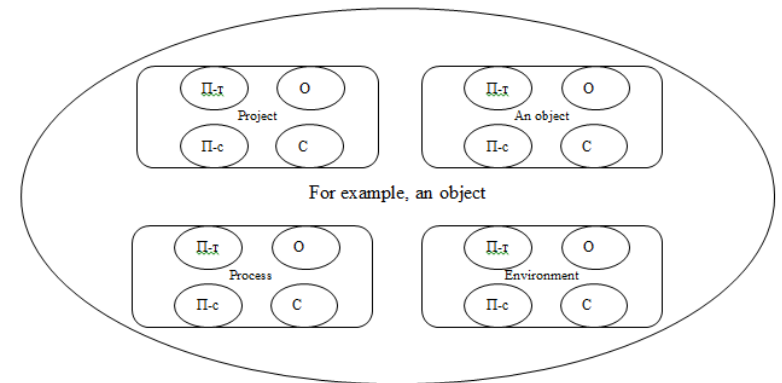

Figure 2 Fractality of the object-design-processenvironmental system

According to the terminology, introduced by B. Mandelbrot, a fractal is understood as structures, having elements of self-similarity at different levels of the system scale. Such a system is a set of self-similar quantity [10]. An important aspect of the fractal process is the emergence of a principal methodological opportunity to analyze the lifetime of the entire system and the path of its movement under the effect of external factors, which is especially important for understanding the development strategy of economic and political systems in society and the state.

The unpredictability of external factors introduces elements of uncertainty and chaos into the nature of the development of the system, the development of a chaotic system is characterized not only by irreversibility, but also by limited predictability. An important characteristic for such a system is the time, during which this system goes into a state of complete chaos, and the system stops to be stable and, accordingly, exist. As a result, after a rather long period of evolution, the memory of the initial state of the system is completely lost: setting the initial state does not allow to determine the path any more. Whereas "under set appropriate initial conditions, we can predict the future with certainty or restore the past" [11]. Thus, as applied to socio-economic and political systems, the problem of understanding the basic principles, on the basis of which these systems are formed, and the preservation of their memory are strategic factors, that determine the possibility of their reproduction and existence. In the conditions of the uncertainty of external factors and the technologically unsolvable task of a complete description of the current state, a prediction for the development of the system can be built only on the basis of a set of scenarios for the development of the system without distinguishing any one path of its movement. In the case of chaotic dynamical systems, the larger the temporal leverage of the prediction, the larger the amount of information, that needs to be processed to describe the current one, i.e. starting state. Identification of similarity elements and understanding the fractal structure of the system makes this process more predictable and makes it possible to optimize and minimize the number of parameters, that characterize the current state of the system. The behavior of a system with identified similarity elements can be analyzed as a quasiresistant structure. Considering a fractal as a quasiresistant state of a system evolving from one state to another, V. Voitsekhovich notes, that a system with elements of similarity overcomes the stage of instability and chaotic state and forms into an ordered total [12].

A change of the basic principles, on the basis of which the system is formed, is a bifurcation point, the passage through which is associated with great uncertainty about the further state of the system.

As applied to socio-economic and political processes in the evolution and development of social relations in the system of the state and society, events, after which the system development vector changes its direction, can be attributed to bifurcation points. At the same time, being at the bifurcation point, it is almost impossible to predict its direction.

The following events in the history of Russia can be identified as examples of bifurcation points in the development of the state and society:

- the abdication of Nicholas II on March 2 (15), 1917, which led to a series of events, that changed the structure of the state-public system of Russia. Moreover, external factors, affecting the system (the Russian Empire), include the war with the German, Austro-Hungarian, Ottoman empires and its alliance with the British Empire and the French Republic;

- the decision of the extended plenary meeting of the Central Committee of the Communist Party of the USSR on February 5, 1990, at which Mikhail Gorbachev declared the necessity of introducing the post of president of the USSR with the simultaneous cancellation of article 6 of the Constitution of the USSR on the leading role of the Communist Party of the USSR and the establishment of a multi-party system. External factors may include the emergence of a powerful social movement in support of nuclear disarmament in the West after the 1962 Caribbean crisis. The disarmament process also had an economic implication: the buildup of the nuclear arsenal carried a huge burden on the state economy;

- $\quad$ "Appeal to the Soviet people" of August 18, 1991 on the introduction of a state of emergency and the creation of the State Emergency Committee. 
As the fact, that the state-society system has passed into a bifurcation point, circumstances, that lead to a change in its Constitution, are specified. Since changing the Constitution or making decisions, that contradict the norms of the working constitution at that time, lead to a change of the state and the entire system of existing social relations. As a result, we immediately get a state, in which no one has lived yet, and no one knows, how to live and how it will be developed. Each one has his own vision and scenario of the future, which is realized as a result of the joint efforts of the whole society through the development of these new rules in the form of adoption of certain laws, and if such a consensus is not developed, the system can self-destruct and descend into chaos. In such a situation, the key to a quasi-resistant state will be the identification of elements of system self-similarity.

In the conditions of digitalization of public relations and the formation of big databases of events and phenomena of the life of society and the state, new opportunities for modeling and predicting scenarios of its development after passing the bifurcation point arise, falling into which is a natural state of an evolving system.

The state as a system consists of various interconnected elements: branches of government, levels of government, individual authorities, people, working in the system of power, etc., these are all components of this system, that continuously interact with each other. And each of this element within the framework of the considered methodology can be represented as a separate subsystem, consisting of its object, environmental, design and process subsystems.

For example, the judicial system consists of the object subsystem (courts), the environmental (regulatory and legal framework, codes), design (transformation, creation of information systems), process (innovation, digitalization). In turn, for example, courts also consist of an object (judges), environmental, design, process subsystems. These subsystems can be considered reference, with their own typical features, but formation of hybrid forms of socio-economic systems are also possible. In turn, legal regulation (the main function is environmental) can be considered as a complex socioeconomic system, consisting of interrelated subsystems: object, design, process, environmental, with many internal interrelations between its constituent elements and an even more complex set of interrelations with the external environment. Legal regulation, when changing (transforming), changes social relations, but also changes itself.

Based on the above, it is possible to formulate the main purposes and objectives of each type of socio-economic systems. The purpose of object systems is to combine dissimilar elements into a single whole when creating a useful product, introducing diversity into the external environment. The purpose of environmental systems is communication and coordination to create conditions for the exchange between the various components of the system. Process systems harmonize, normalize the state and activity of other subsystems. The purpose of design systems is the innovative transformation of other systems, changing the socio-economic space. It is possible to say, that projects determine the dynamics of object systems, processes - the dynamics of environmental systems.

When developing a development strategy for a complex socio-economic system, the identification and taking into account the synergetic properties of this system will be of great importance for the analysis of its effectiveness. The combination of individual elements of the system can be considered successful and appropriate if they interrelate in such a way to give a synergistic effect. In general, synergy is interpreted as the fact, that the total result of all interacting factors is higher, than the simple sum of these factors before they start the interaction process [13].

Mathematically, we can represent the effect of the external environment on any social system by describing the state of the system as a set of states of the object subsystem (bo), design subsystem (ьпрт), process subsystem (bпрс), environmental subsystem (bc). The environment itself is set by a $4 \times 4$ matrix.

$$
\left(\begin{array}{cccc}
r_{\text {о,о }} & r_{\text {о,прт }} & r_{\text {о,прс }} & r_{\text {о, }} \\
r_{\text {прт, }} & r_{\text {прт,прт }} & r_{\text {прт, прс }} & r_{\text {прт, }} \\
r_{\text {прс, }} & r_{\text {прс,прт }} & r_{\text {прс,прс }} & r_{\text {прс, }} \\
r_{\mathrm{c}, \mathrm{o}} & r_{\mathrm{c}, \text { прт }} & r_{\mathrm{c}, \text { прс }} & r_{\mathrm{c}, \mathrm{c}}
\end{array}\right)
$$

The first line is the change of the object system through the influence of the external environment on all four subsystems. The second line is the change of the design system through the influence of the external environment on all four subsystems. The third line is the change of the process system through the influence of the external environment on all four subsystems. The fourth line is the change of the environmental system through the influence of the external environment on all four subsystems.

As a result of the affection of the external environment on the system, we obtain a new state of the socio-economic system, in which all subsystems will change in general:

$$
\begin{aligned}
& \left(\begin{array}{cccc}
r_{\text {о,о }} & r_{\text {о,прт }} & r_{\text {о,прс }} & r_{\text {о, с }} \\
r_{\text {прт, },} & r_{\text {прт, прт }} & r_{\text {прт, прс }} & r_{\text {прт, }} \\
r_{\text {прс }, 0} & r_{\text {прс,прт }} & r_{\text {прс,прс }} & r_{\text {прс, }} \\
r_{\mathrm{c}, 0} & r_{\mathrm{c}, \text { прт }} & r_{\mathrm{c}, \text { прс }} & r_{\mathrm{c}, \mathrm{c}}
\end{array}\right) *\left(\begin{array}{c}
b_{\mathrm{o}} \\
b_{\text {прт }} \\
b_{\text {прс }} \\
b_{\mathrm{c}}
\end{array}\right)=
\end{aligned}
$$

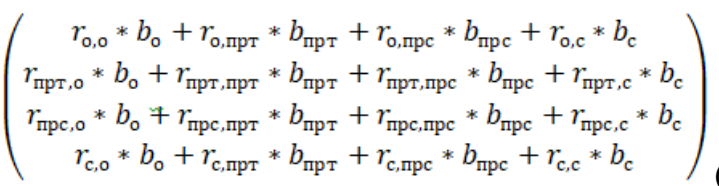

In accordance with this model, we can conclude, that even if there is no environmental effect directly on the object system $\left(r_{o, o}=0\right)$, the object system will still change. This model allows to take into account all the variety of external effect through the interrelation of the reaction of the object, design, process and environmental subsystems to it. Moreover, their interrelation acts as elements of an order, that preserves the memory of previous states of the system and ensures its reproduction during evolutionary development as a self-similar quasi-resistant to external effects system. 
angliyskogo E. L. Nappel'bauma, pod red. S. V. Yemel'yanova - M.: Mir, 1978.

\section{CONCLUSIONS}

The consideration of socio-economic and socio-political phenomena from the point of view of the system paradigm allows to represent them as a set of interacting, transforming and evolving subsystems and to reveal their fractal nature. Digitalization provides new opportunities for revealing the variety of these systems through the implementation of various technological and mathematical solutions, the creation of appropriate models. Disclosing the fractal nature of socio-economic systems allows to form models for their development, taking into account the emerging uncertainties, associated with their interaction with the environment. The presented mathematical model allows to take into account the variety of external effects through the interrelation of the reaction of the object, design, process, and environmental subsystems to it.

\section{ACKNOWLEDGMENT}

The study was carried out with the financial support of the RFBR as a part of the scientific project No. 18-29-16111

\section{REFERENCES}

[1] I. V. Blauberg, V. N. Sadovskiy, E.G. Yudin, Sistemnyy podkhod $\mathrm{V}$ sistemnoy nauke, problemy metodologii sistemnogo issledovaniya. - M., Mysl', 1970.

[2] S. Yang, Sistemnoye upravleniye organizatsiyey / Per. s angl. Pod red. S. P. Nikanorova, S. A. Batasova // M.: «Sovetskoye radio», 1972. 456 s.

[3] V.B. Britkov i dr., Sotsial'naya informatika: osnovaniya, metody, perspektivy : [monografiya] / [V. B. Britkov i dr. ; redkol.: V. V. Kelle, N. I. Lapin, V. N. Sadovskiy] ; In-t sistem. analiza Ros. akad. nauk, In-t sots. informatiki Mezhdunarod. akad. nauk inform., inform. protsessov i tekhnologiy. - Izd. 2-ye, ster. Moskva : URSS, 2006. - 208 s.

[4] L. fon Bertalanfi, Obshchaya teoriya sistem: kriticheskiy obzor. Available at: http://grachev62.narod.ru/bertalanffy/bertalanffy_1.htm 1 Istochnik: Issledovaniya po obshchey teorii sistem: Sbornik perevodov / Obshch.red. i vst. st. V. N. Sadovskogo i E. G. Yudina. - M.: Progress, 1969. S. 23-82.

[5] M. Mesarovich, YA. Takakhara, Obshchaya teoriya sistem matematicheskiye osnovy. / Perevod s
[6] YA. Kornai, Sistemnaya paradigma // Voprosy ekonomiki. 2002. № 4. S. 4-22.

[7] G.B. Kleyner, Strategicheskoye planirovaniye: osnovy sistemnogo podkhoda. Available at: https://www.hse.ru/data/372/665/1234/\%D0\%9A $\%$ D0\%BB $\%$ D0\%B5\%D0\%B9\%D0\%BD $\%$ D0\%B5\%D1\%80.doc

[8] G.B. Kleyner, M.A. Rybachuk, Sistemnaya sbalansirovannost' ekonomiki Rossii: regional'nyy razrez // Ekonomika regiona. 2019. T. 15. № 2. S. 309323. DOI: https://doi.org/ 10.17059/2019-2-1

[9] G.B. Kleyner, Sistemnaya paradigma i sistemnyy menedzhment // Rossiyskiy zhurnal menedzhmenta. 2008. T. 6. № 3. C. 27-50.

[10] Mandelbrot B.B. Les objects fractals: Forme, hasard et dimension, Paris: Flammarion. 1975. 220 r.

[11] I. Prigozhin, Konets neopredelennosti. Vremya, khaos i novyye zakony prirody. Izhevsk: NITS Regulyarnaya khaoticheskaya dinamika. 2000. 208 s.

[12] V.E. Voytsekhovich, Matematicheskiye teorii sinergetiki // «Ustoychivoye razvitiye v izmenyayushchemsya mire». Moskovskiy sinergeticheskiy forum. 27-31.01.96. Tezisy dokladov. M. 1996. S. 46.

[13] Dzh. K. Lafta, Teoriya organizatsii. M., 2006. $-416 \mathrm{~s}$. 